\title{
Innatist and Interactionist Learning Approaches of Elementary School Students' Language Acquisition
}

\author{
Petra Kristi Mulyani \\ Department of Curriculum and Instruction, Southern Illinois University Carbondale, USA \\ Email: petra.mulyani@mail.unnes.ac.id
}

\begin{abstract}
Language acquisition starts in childhood. Oral language is the initial language to learn. Within it, lies norms to make language functional. Children start to function the language through communication. Communication provides an identity that shapes them into different settings. As language acquisition is unique and individual, experts have been studying to interpret it. There are at least three theorists of language acquisition. They are a behaviorist, innatist, and interactionist. Experts are debating on which theory provides the most appropriate approaches for the students. The discussion will compare innatist and interactionist approaches to the students' first and second language acquisition. It describes how the educational program would be like when using innatist and interactionist learning approaches. There are also critiques on innatist and interactionist approaches. A suggestion is provided to strategically integrate both approaches to understand language acquisition process in both first and second language students.
\end{abstract}

Keywords: innatist; interactionist; first and second language acquisition

\section{INTRODUCTION}

Students acquire language since their childhood (Peregoy \& Boyle, 2013). They recognize and learn the oral language as their initial language. As they acquire the language, they start to understand the norms and styles that involve. It is when their written and gestural language also start to develop. Their language is functional. It is for communication and group identity. Thus, as they are proficient in the language, they will be able to use it in any setting like home, school, and society.

At school, students are expected to be competent in speaking, listening, writing, and reading with different genres (Peregoy \& Boyle, 2013). It includes the competence in understanding structural rules, vocabulary choices, and pragmatics. Student's language acquisition process is different from one to another. It is a unique and individual process. To understand the process, many experts tried to study and make an interpretation. Peregoy and Boyle (2013) mentioned that:
... neither first nor second language acquisition is yet fully understood. As a result, many controversies and disagreements prevail among experts. Therefore, continued interdisciplinary research in psycholinguistics, sociolinguistics, and education is needed to better understand the processes of language acquisition and use. (p. 57)

The theories of language acquisition consist of behaviorist, innatist, and interactionist (Lightbown \& Spada, 2006). Behaviorist emphasizes learning in stimulus, response, and reinforcement. The positive reinforcement in the form of praise or successful communication appears when children can imitate the modeled language. As children continue to produce the language, they will gradually shape their habit. Innatist believes language acquisition development in children is the same as the development of their biological function. It is the innate 
factor that causes their language development process. Interactionist mentions the importance of caregiver in facilitating children's language acquisition. Caregiver plays a vital role to help the children in using the language for social interaction communication.

There are debates among the three theories on which approach works better to support students' language acquisition learning process at school. Although all approaches give influence in language teaching, there is a significant critique towards behavioral approach. Language teaching strategies recently focus on innatist and interactionist approaches. These two approaches complete one and another in building ideal language classroom composition to the students (Peregoy \& Boyle, 2013). Thus, this article will focus on the discussion of innatist and interactionist approaches in elementary school students' language acquisition. There will be a discussion on the review from the theorists, as well as the research on its learning practice. There is also discussion on critiques of innatist and interactionist theory. The statements of problems that lead the discussion will be:

- What are the most appropriate learning approaches to develop elementary school students' language acquisition? Are innatist and interactionist the most appropriate approaches to the students' first and second language acquisition?

- How would the educational program be like when using innatist and interactionist learning approaches?

- What are the critiques of innatist and interactionist approaches?

\section{DISCUSSION}

Swanson et al. (2013) mentioned that elementary school students' English language acquisition learning encountered many problems from many aspects; affected the students who had English as their first or second language. The causes of the problems were various. The obvious cause was regarding whether English became their native language or not. Second language learners were reported to have reading difficulties across various elementary school grade level. Also, learning approach became a significant factor that affected elementary school students' language proficiency. Students' language proficiency affected their academic performance. English language acquisition learning had different and individualized process between one and another student in elementary school. However, no matter whether English became students' first or second language, the poor language proficiency proofed to affect the same negative impact towards their school achievement.
Bui and Fagan (2013) added that language learning in elementary school nowadays had to deal with school system and curriculum that put pressure on teacher and students. The elementary school teacher was demanded to perform the most suitable approach to support students' language learning within the diverse settings of first and second English language learners, having different backgrounds. Teachers also needed to face the different achievement gaps among the students having different language background. Elementary school students having English as their second language performed lower achievement because of their lower language proficiency to function the learning process.

In facing the students' problems related to English language acquisition in elementary school, some theories provided approaches to building language learning practices in the language classroom. Innatist and interactionist learning approaches are considered to be valuable for elementary school students' language acquisition. Here are the discussions about the approaches.

\section{Innatist Theory}

\section{First Language Acquisition Perspective}

Noam Chomsky (2002) stated the innatist theory. He mentioned that children were born with the ability to acquire language (innate). He argued that language acquisition of children be related to their innate ability of biological language acquisition device (LAD). It meant that infants were prewired to analyze linguistics. In his book, Chomsky (2002) provided analysis of syntax that supports his innatist theory. He claimed that infants had innate universal grammar. Universal grammar was the template possessed by the children since they were born. As they grew, they would face language functions. It was when they were exposed to the language that grammar was gradually constructed. Children tried to make hypothesis instead of imitating the language. The rule of plural nouns, for example, would make the students learn that $-s$ ending was necessary for plural nouns. However, as they experienced the language, they would revise their hypothesis by not using $-s$ ending to all nouns in creating plural nouns. It was when they used the rule from their hypothesis instead of just repeating others.

\section{Second Language Acquisition Perspective}

Chomsky (2002) also inspired innatist theory in second language perspective. According to research by Dulay and Burt (1974), the majority of grammatical error made by young second English language learners were the similar to young first English language learners. They 
made research of Spanish-speaking, Chinese-speaking, and English-speaking students. Students were interviewed to respond to the questions based on the colorful cartoon pictures. They were expected to answer the questions with specific grammatical structure. The study revealed that some grammatical error made by Spanish-speaking and Chinese-speaking students as the influence of their first language. However, English-speaking students had the same majority of grammatical errors with second language learners.

The conclusion of Dulay and Burt (1974) research had explained innatist perspective in second language acquisition. They called second language learner innate ability with so-called creative construction theory. Although the process of acquiring first and second language was not identical, however, it showed the similar process. Students constructed the rules of the second language creatively that it did not depend on their first language construction. Contrastive analysis to compare phonological, morphological, and syntactic rules to guess second language learners' success was not applicable based on their research. Thus, having innatist approach towards second language acquisition learning would still be effective to help the students to acquire their second language.

\section{Interactionist Theory}

\section{First Language Acquisition Perspective}

Interactionist believed the importance of nature and nurture in the children's language acquisition process (Lightbown \& Spada, 2013). Caregivers help the children to make the language function properly in the society. The language ability that innately possessed by the children would complete by the process of adjusting the language for the correct purpose and context. It is when caregivers take their essential role. With the help of caregivers, the children acquire more vocabulary. In the meaningful conversation, caregivers often question, answer, challenge, and contradict to build the children's nuances on the language. As children progress to construct the meaning of the language, they will get help to construct the meaning of the vocabulary within the right context and use. Social interaction becomes one of the keys to build children's language proficiency. The social environment is the key to process their language acquisition.

\section{Second Language Acquisition Perspective}

Interactionist in the perspective of second language acquisition process focuses on the interaction between the native and non-native speakers or first language and second language learner. The interaction between the two sides will help second language learner to acquire the language. There is a mutual interaction named negotiation of meaning (Long \& Porter, 1985). It involves the process of give-and-take and trial-and-error. The native speaker will modify their language production to be understood by a non-native speaker. On the other hand, the non-native speaker will try to produce language that is understood by the native speaker. During the process, other means can help the communication succeed like gesture and picture.

Peregoy and Boyle (2013) explained that interactionist learning approach in the classroom should provide the opportunity for native and non-native speakers to learn the ways to make the communication. It involved the skills in asking for clarification, expressing ideas, expressing meaning, and understanding gestures.

\section{Educational Program Using Innatist And Interactionist Learning Approaches}

The teacher should carefully plan educational program using innatist and interactionist learning approaches. To be able to plan the educational program, the teacher needs to understand well the difference between innatist and interactionist perspective. It is important because developing the program without knowing the character of each approach will lead to the activities represent a different approach. The following is a summary of the two theories (Peregoy \& Boyle, 2013, p. 62):

Table 1. Innatist and Interactionist Language Acquisition

\begin{tabular}{|c|c|c|}
\hline $\begin{array}{c}\text { Acquisition } \\
\text { Aspects }\end{array}$ & $\begin{array}{c}\text { Innatist } \\
\text { Perspective }\end{array}$ & $\begin{array}{c}\text { Interactionist } \\
\text { Perspective }\end{array}$ \\
\hline $\begin{array}{c}\text { Linguistic } \\
\text { Focus }\end{array}$ & child's syntax & $\begin{array}{c}\text { conversation } \\
\text { between child } \\
\text { and caregiver }\end{array}$ \\
\hline $\begin{array}{c}\text { Process of } \\
\text { acquisition }\end{array}$ & $\begin{array}{c}\text { hypothesis } \\
\text { testing }\end{array}$ & communication \\
\hline $\begin{array}{c}\text { creative } \\
\text { construction }\end{array}$ & $\begin{array}{c}\text { caregiver } \\
\text { scaffolding }\end{array}$ \\
\hline Role of child & $\begin{array}{c}\text { primary using } \\
\text { LAD }\end{array}$ & $\begin{array}{c}\text { important in } \\
\text { interaction }\end{array}$ \\
\hline $\begin{array}{c}\text { Role of } \\
\text { environment }\end{array}$ & minor & important \\
\hline
\end{tabular}

The discussion about second language perspectives provides a summary of instructional implications on both theories. The following is the summary (Peregoy \& Boyle, 2013, p. 67): 
Table 2. Second Language Acquisition Instructional Implications

\begin{tabular}{|c|c|c|}
\hline $\begin{array}{l}\text { Instructional } \\
\text { Components }\end{array}$ & Innatist & Interactionist \\
\hline $\begin{array}{l}\text { Source of } \\
\text { linguistic } \\
\text { input }\end{array}$ & $\begin{array}{l}\text { natural language } \\
\text { from teacher, } \\
\text { friends, books }\end{array}$ & $\begin{array}{l}\text { natural language } \\
\text { from teacher, } \\
\text { friends, books }\end{array}$ \\
\hline $\begin{array}{l}\text { Nature of } \\
\text { input }\end{array}$ & $\begin{array}{l}\text { unstructured, } \\
\text { made } \\
\text { comprehensible } \\
\text { by teacher }\end{array}$ & $\begin{array}{l}\text { unstructured, } \\
\text { focused on } \\
\text { communication } \\
\text { with others }\end{array}$ \\
\hline $\begin{array}{c}\text { Ideal } \\
\text { classroom }\end{array}$ & $\begin{array}{l}\text { target language } \\
\text { learners' similar } \\
\text { second language }\end{array}$ & $\begin{array}{l}\text { native speakers } \\
\text { and language } \\
\text { learner for } \\
\text { communication }\end{array}$ \\
\hline Student output & $\begin{array}{l}\text { not a concern, } \\
\text { will occur } \\
\text { naturally }\end{array}$ & $\begin{array}{c}\text { natural } \\
\text { communication } \\
\text { with others }\end{array}$ \\
\hline $\begin{array}{l}\text { Pressure to } \\
\text { speak }\end{array}$ & $\begin{array}{l}\text { silent period } \\
\text { expected }\end{array}$ & $\begin{array}{c}\text { no pressure } \\
\text { except natural }\end{array}$ \\
\hline \multirow[t]{2}{*}{$\begin{array}{l}\text { Treatment of } \\
\text { errors }\end{array}$} & $\begin{array}{l}\text { not corrected, } \\
\text { with time }\end{array}$ & $\begin{array}{l}\text { corrected } \\
\text { naturally as } \\
\text { meaning }\end{array}$ \\
\hline & $\begin{array}{l}\text { students correct } \\
\text { themselves }\end{array}$ & $\begin{array}{l}\text { is negotiated, } \\
\text { some explicit }\end{array}$ \\
\hline
\end{tabular}

Understanding the difference between the two theories, these are some suggested educational programs to consider as the combination between the two learning approaches:

\section{Conversational Scaffolding}

There are several steps in conversational scaffolding activity (Ninio \& Bruner, 1978). In the beginning, the student makes a sentence. Then the instructor or teacher repeats the student's statement by providing a more expanded form of a sentence. While the student is modeling the sentence usage, $\mathrm{s} /$ he checks the understanding of the new sentence. At the end of the interaction, questions scaffold their participation in communication. Scaffolding will build the students' language acquisition through the development of the vocabulary and meaning.

\section{Dialogue}

The dialogue directs to communication that involves questioning, answering, challenging, and contradicting (Halliday, 1994). The components of the dialogue matter because it builds the students' concept to understand the meaning and the nuances of the words and phrases produced during the communication. Students have the chance to interact with the social environment in conducting the dialogue. Activities can be inside or outside the classroom. Guest speakers can also become the alternative for the students to get exposed to the society.

\section{Krashen's Five Hypotheses}

a. The Acquisition / Learning Hypothesis

Activities in the classroom involve native speakers into the process (Krashen, 1982). Students need to experience the encounter with the native speakers because they need the ideal model of their language production. The instruction of communication should be given explicitly to make the students aware of the rules of their hypothesis.

b. The Monitor Hypothesis

Activity within this program needs the students to apply their hypothesis by making communication (Krashen, 1982). The communication of their ideas is done orally and written. In communicating their ideas, students are required to explicitly tell their understanding of the rules of language based on their hypothesis. Partners, instructor, or teacher can be their partner in communication.

\section{c. The Natural Order Hypothesis}

The educational program in this hypothesis provides students with the chance to experience the acquiring process of the language. The instructor or teacher builds the experience within specific expected grammatical features that can be acquired by the students. Specific dialogs within certain themes are provided for the students to acquire the grammatical features involved in the activity (Krashen, 1982).

\section{d. The Input Hypothesis}

Students have the experience of natural communication with the society. The activity is outside of the classroom setting. Teacher or instructor chooses the setting that has language level with a little bit beyond the students' level. Thus, students will develop their language level in a natural setting (Krashen, 1982).

e. The Affective Filter Hypothesis

Communication setting is ensured to be less pressure for the students. Students should not be forced to produce a language of specific standards. It is because the teacher understands that they sometimes need a silent period to acquire the language. Thus, teacher or instructor can provide activities when students do not have burdens of particular assignments. There is activity when students only listen and enjoy for being 
in the language setting. The activities can be watching movies or drama without any assignment that follows.

4. Negotiation of Meaning (Long \& Porter, 1985)

Activities can be for students to understand the importance of negotiation in meaning. Teacher or instructor provides conversation activities where students need to use gesture or drawing to convey the meaning (Krashen, 1982). Activities can be in small or big groups, for example, games of gesture guessing or drawing guessing.

\section{Critiques of Innatist and Interactionist Learning Approaches}

Innatist and interactionist learning approaches have critiques from many experts. Gardner (1995) mentioned that Chomsky's innatist theory did not regard the role of parents and caregivers towards the children's language development. It was unacceptable because adults were needed to make the language functioned adequately. Language should be socially accepted. Children were regarded to be a proficient language learner only when they could produce language within the specific construction of meaning. This process would need adults to complete. Thus, innatist would not complete without interactionist perspective.

Rhyner (2007) made a study about the role of caregiver in the language development of the children. Because children nowadays are enrolled in childcare centers, the language input from caregivers could play a significant role in children's language development. During book sharing, children record caregiver language. The language structures recorded included declarative, imperative, wh- questions, yes/no questions, choice questions, compound, and complex sentence, and other structure possible to occur during the book sharing activity. The language structures were used to demonstrate a communicative style with the children. The children acquired language as the caregiver introduced and repeated during the activities. This study supported interactionist theory on the role of caregiver (nurture) to the children's language acquisition. However, there was a critique that interactionist limited the students' language development. They would only develop their language based on the input of the caregiver. The caregiver limited their creativity.

Chapman (2000) discussed many aspects that influenced children's language learning from the perspective of interactionist theory. Although many factors were nature, nurture also took part in the way children acquired language. The genetical and biological condition of children would affect their language development. Environmental inputs also contributed. The positive verbal interaction between parents and child had proven to be supportive towards fast language development. The environment provided variations of their language system. Cross-linguistic and cross-cultural developed language system to be functional. This study provided a more in-depth theoretical understanding of how interactionist perspective discusses each aspect that influenced children's language development. However, as well as Rhyner's study, interactionist invites critique. Students would only limit their cross-cultural understanding on the environment provided for them. They might not be able to experience broader crosscultural perspectives besides their environment.

Sato (2015) investigated conversation between second language learner and native speakers. The interaction is examined in MLU (mean length of utterance), types and tokens of words, TTR (type-token ratio), copula omissions, and the number of types of verbs and nouns. The study found that although native speakers had more grammatical and lexical variability, they tended to omit some to balance with second language learners' errors. We could see that native speakers tried to adapt to produce a good communication with second language learners. The result found that second language learners acquired more verbs from the interaction through conversation with native speakers. This study provided educational practice with interactionist approach on how to develop second language learner's words through interaction with native speakers. The critique of the interactionist in this study was related to the concern of the development of the native speakers. The concept of buddying the second language learners to the first language learner might give burden to the native speaker to grow. Buddying would consume the time and chances for a native speaker to grow more.

Shanker (2002) provided a detail description of how Chomsky's theory provided cognitivist approach on the focus of children's language development theory. Chomsky (2002) believed that children were born with the ability to acquire language (innate). Besides, there were descriptions to compare between cognitivist and behaviorist approach in explaining how children acquired language. However, Specific Language Impairment (SLI) discussed in the article had provided the view of interactionist approach that took part in students' language development. Through interaction with the environment, the language functioned for the communicative purpose, even for SLI children. This study questioned the accurateness of innatist idea towards SLI children. An innate capability might not be able to explain 
this circumstance. SLI children should accept special approach for students' disability than innatist.

Seidenberg (1997) discussed an innate aspect of children's language acquisition. A debate on behaviorist point of view was presented to refute innatist approach. The argument was children would not be able to acquire grammatical knowledge without behavioral learning approach. However, there was another argument that children had an innate knowledge of the grammatical structure or universal grammar. The discussion in the article revealed important emphasizes on how each learning approach discussed the logic view of how language was acquired. It also provided the logic view from each approach on how to use language. In fact, the teacher might still use behaviorist approach more than innatist.

Eckman (2004) provided comprehensive discussion about Universal Grammar by Chomsky. Besides, there was a discussion about language typology. Both approaches explained how to develop second language acquisition. The article discusses several arguments. The arguments were about the innate aspect of children in acquiring their second language were not the same as first language acquisition. Language typology was presented to give another point of view on how the second language was acquired and better explained the acquisition process than innatist theory. It was presented to explain the way human brain worked with second language acquisition process. It helped to understand that innate language learning approach could not explain how second language learners acquire their language.

Radick (2016) provided a complete description of Chomsky's way of thinking. He explained that Chomsky used to be a behaviorist. However, Chomsky transferred to cognitivist as he discussed on transformational generative grammar. There were discussions on how Chomsky looked at Hockett work, that he finally dedicated himself to the view of children language acquisition. The article also discussed the reasons why Chomsky was chosen as the alternative in explaining children language acquisition process. Views were provided to open the understanding of the role of behaviorist towards the emergence of Chomsky theory. Thus, it questioned Chomsky's motives in creating innatist theory.

Cohen-Cole (2015) discussed the history of psycholinguistics. There were discussions of psychologist George Miller and the linguist Noam Chomsky. Both theorists were discussed in the article to provide a different point of view on how language acquisition theory was debated. Debates were presented to discuss innatist theory that was weak in explaining the logic of social role in language acquisition process. The author suggested the reader understand various views in understanding how language works within different approaches to help to understand that children were different from one to another. Thus, different views would help to understand different aspects of students in acquiring language.

\section{CONCLUSION}

Discussion on innatist and interactionist learning approach for elementary school students' language acquisition has to lead us to the conclusion that both should be used within the context of completing each other. We understand that innatist learning focuses on the approach to the students' innate capability that many times give them the chance to grow their self-esteem and self-confidence. In fact, integrating interactionist into innate learning process will make the educational program better facilitate first and second language learners to build their proficiency. Though many critiques appear to both approaches, the teacher can take the benefits and make use of innatist, and interactionist learning approaches towards the success of students' language acquisition.

\section{REFERENCES}

Bui, Y. N., \& Fagan, Y. M. (2013). The effects of an integrated reading comprehension strategy: A culturally responsive teaching approach for fifthgrade students' reading comprehension. Preventing School Failure, 57(2), 59-69. doi:10.1080/104598 8X.2012.664581

Chapman, R. S. (2000). Children's language learning: An interactionist perspective. Journal of Child Psychology and Psychiatry and Allied Disciplines, 41(1), 33-54.

Cohen-Cole, J. (2015). The politics of psycholinguistics. Journal of The History of The Behavioral Sciences, 51(1), 54-77. doi:10.1002/jhbs. 21700

Chomsky, N. (2002). Syntactic structures (2nd ed.). Berlin, NY: Mouton de Gruyter.

Dulay, H. C., \& Burt, M. K. (1974). Errors and strategies in child second language acquisition. TESOL Quarterly, 8(2), 129-136. doi: $10.2307 / 3585536$

Eckman, F. R. (2004). Universals, innateness, and explanation in second language acquisition. Studies in Language, 28(3), 682-703.

Gardner, H. (1995). Green ideas sleeping furiously. The New York Review of Books, 42(5), 32., NYRetrieved from https://www.sscnet.ucla.edu/comm/steen/cogweb/ Abstracts/Gardner_95.html

Krashen, S. D. (1982). Principles and practices in second 
language acquisition. Oxford: Pergamon.

Lightbown, P., \& Spada, N. (2006). How languages are learned (3rd ed.). Oxford: Oxford University Press.

Long, M. H., \& Porter, P.A. (1985). Group work, interlanguage talk, and second language acquisition. TESOL Quarterly, 19(2), 207-228. doi: 10.2307/3586827

Ninio, A., \& Bruner, J. (1978). The achievement and antecedents of labelling. Journal of Child Language, 5(1), 1-15. doi:10.1017/S0305000900001896

Peregoy, S. F., \& Boyle, O. F. (2013). Reading, writing, and learning in ESL: A resource book for teaching $K-12$ English learners (6th ed.). Boston, MA: Pearson.

Radick, G. (2016). The unmaking of a modern synthesis: Noam Chomsky, Charles Hockett, and the politics of behaviorism, 1955-1965. ISIS: Journal of The History of Science in Society, 107(1), 49-73.

Rhyner, P. M. (2007). An analysis of child caregivers' language during book sharing with toddler-age children. Communication Disorders Quarterly, 28(3), 167-178.

Sato, M. (2015). Density and complexity of oral production in interaction: The interactionist approach and an alternative. IRAL: International Review of Applied Linguistics in Language Teaching, 53(3), 307-329. doi:10.1515/iral-2015-0016

Seidenberg, M. S. (1997). Language acquisition and use: Learning and applying probabilistic constraints. Science, 275(5306), 1599-1603.

Shanker, S. (2002). The generativist-interactionist debate over specific language impairment: Psycholinguistics at a crossroads. American Journal of Psychology, $115(3), 415-450$.

Swanson, H., Orosco, M., Lussier, C., Gerber, M., \& Guzman-Orth, D. (2013). The influence of working memory and phonological processing on English language learner children's bilingual reading and language acquisition. Journal of Educational Psychology, 103(4), 838-856. 